\title{
Children and Persuasive Advertising: Drawing the Line between Peripheral and Informative TV Commercials
}

\author{
Gennadi Gevorgyan ${ }^{1}$ \& Naira Manucharova ${ }^{2}$ \\ ${ }^{1}$ Department of Communication Arts, Xavier University, Cincinnati, OH, USA \\ ${ }^{2}$ Consulate General of Republic of Armenia, Los Angeles, CA, USA \\ Correspondence: Gennadi Gevorgyan, Xavier University, 3800 Victory Parkway, Cincinnati, Ohio, USA. Tel: \\ 1-513-745-2954. E-mail: gevorgyang@xavier.edu
}

Received: June 13, 2012 Accepted: June 29, 2012 Online Published: August 21, 2012

doi:10.5539/jpl.v5n3p15 URL: http://dx.doi.org/10.5539/jpl.v5n3p15

\begin{abstract}
With a goal of revealing the unique vulnerability of children in the face of advertisers' targeting efforts, we revisit the philosophical and legal frameworks underlying the regulation of commercial speech that targets children. In doing so, we reexamine the rationale behind the constitutional protection of advertising within the context of children's information processing patterns and the manipulative nature of persuasive speech. We argue that some of the fundamental assumptions that underlie the protection of commercial speech lack validity when applied to children surrounded by today's technologically advanced marketplace. We further argue that in regulating persuasive advertising, government should be given more leeway than it currently has under the Central Hudson test. Moreover, we believe that targeting children with persuasive messages should be proscribed on the grounds of being misleading under the Federal Trade Commission's standard for deceptive commercial speech.
\end{abstract}

Keywords: advertising, regulation, children, government, marketing, philosophy, ethics

\section{Introduction}

Each year, more than two billion of advertising funds are invested in targeting children (Cabletelevision Advertising Bureau, 2006). In a given year, children spend about 600 hours more in front of the TV than they spend in the classroom. Fifty three percent of children aged 2-18 years have a TV set in their bedrooms (Walter, Schwartz, Angelini, \& Rideout, 2007). They are exposed to at least one hour of commercial for every five hours of programs. As a result, by the age of 21, they see about one million television commercials. Heavy television viewing has clear purchasing implications. Children of four years old and under influence about 190 billion dollars in family purchases. In 2000 alone, children aged four spent over 29 billion of their own money on a variety of goods, including toys, candies, and CD's. Moreover, studies have shown that the amount of television viewing was a major predictor of the frequency of children's product-purchase requests (Bakir \& Vitell, 2010). The extended and frequent exposure to advertising, among other things, increases children's sense of materialism, which, in turn, leads to higher rates of emotional problems, fewer friends, and poorer grades (Levine, 2007).

Recent decades of telecommunication history have been characterized by rapid technological advancements and sophistication of marketing technologies. Industrialization, increased competition, and need for product differentiation made television switch its focus from mass audiences to niche markets (Collins, 2008; Kolish \& Enright, 2010). As Sheehan points out, with a constrained channel capacity, television programming aimed at children was limited in amount (2004). The new multi-channel era, on the other hand, is characterized by abundant national program services directed primarily at children (e.g. ABC Family, Cartoon Network, Disney Channel). These channels supply ample child-oriented advertising messages, including commercial segments, product sponsorships and placement. Moreover, an increasing number of advertising and media planning agencies rely on child psychologists who draw upon the principles of developmental and cognitive psychology to cultivate favorable attitudes toward advertised products and to make children influence their parents to purchase these products (Morgan, Fairchild, Phillips, Stewart, \& Hunter, 2009). Kids as Customers: A Handbook of Marketing to Children, What Kids Buy and Why: The Psychology of Marketing to Kids, and Creating Ever-Cool: A Marketer's Guide to a Kid's Heart are examples of scholarship that has been developed and applied to effectively target children. 
With increasing consumerism of our society and the children becoming a lucrative target and a rapidly growing market for advertisers, it seems important to revisit the legal grounds on which marketers develop and execute their persuasive advertising campaigns. We address this issue by reexamining the rationale for freedom of expression within the context of children's information processing patterns and the manipulative nature of persuasive speech. We argue that some of the fundamental assumptions that underlie the constitutional protection of commercial speech lack validity when applied to children targeted by persuasive speech. We further contend that, in regulating persuasive advertising, government should be given more leeway than it currently has under the Central Hudson test. Moreover, targeting children with persuasive messages should be proscribed on the grounds of being misleading under the Federal Trade Commission's standard for deceptive commercial speech.

\section{Advertising Regulation: Historical and Current Status}

In 1942, the Supreme Court ruled that the government had unlimited power to proscribe advertising because commercial speech shouldn't have any First Amendment protection (Valentine v. Chrestensen, 1942). Later overturned, advertising in 1940s was treated as a form of commercial activity that could be regulated by any manner government considered reasonable. By giving First Amendment protection to a paid political criticism in New York Times v. Sullivan (1964), the Supreme Court took an initial step toward providing constitutional status to commercial speech. A little more than 10 years after, the Court explicitly recognized that commercial speech deserved First Amendment protection (Virginia State Board of Pharmacy v. Virginia Citizens Consumer Council, 1976). By striking down a state statute that prohibited price advertisements for prescription drugs, the Court recognized advertising as a form of commercial speech and gave it a degree of First Amendment protection to ensure people's interest in the free flow of commercial information and to facilitate consumer decision making. The Court, however, noted that the protection of commercial speech had only secondary position in the ranking of First Amendment rights (Ohralik v. Ohio State Bar Association, 1978). The first level, the highest protection, has been given to political, cultural, and artistic speech. This speech is protected because it is believed to be crucial for the functioning of a democratic society. The next level, commercial speech, is given relatively less protection. The Supreme Court has allowed some regulations of commercial speech that would not have been allowed for political speech. As Middleton and his associates pointed out, the government must demonstrate a "lesser" substantial need or interest to justify restrictions on commercial advertising (1997). The Court also noted that prior restraints, which are presumed unconstitutional in the political communicational sphere, may be used to stop deceptive commercial speech.

When it comes to commercial speech, the general rule is that the speaker and the public, not the state, assess the value of the communicated information. Even a communication that does no more than offer a commercial transaction is entitled to First Amendment protection (Edenfield et al. v. Fane, 1993). In Edenfield v. Fane, for example, the Court struck down a state statute prohibiting Certified Public Accountants from engaging in direct and uninvited commercial solicitation.

Starting from 1980, constitutional merits of advertising regulations have been evaluated using the Hudson test, a standard that derived from a famous Supreme Court Case, Central Hudson Gas \& Electric v. Public Service Commission of New York (1980). In this case, Central Hudson launched an advertising campaign promoting their electronic appliances when the country was facing an energy crisis. The Public Service Commission tried to proscribe the campaign in an attempt to stop consumers from purchasing products that could increase energy use. The Court overturned the Public Commission's regulation of Central Hudson's promotional advertising by rejecting the state's claim that a utility's monopoly status justified a ban on advertising. The Court didn't agree with the idea that advertising is useless in noncompetitive and concentrated markets. In clarifying the extent of commercial speech protection, the Court established a four-prong test to balance advertisers' constitutional rights and social interests. First, the commercial speech must involve lawful activity and not be misleading (1). If an advertisement doesn't meet the first part of the test, then the government can proscribe it without addressing the rest of the test. If, however, commercial speech at issue concerns a lawful activity and is not misleading, the government must demonstrate substantial interest in regulating the speech (2). Furthermore, regulation must directly advance the stated interest (3). Moreover, the regulation must not be more extensive than necessary to serve that interest (4). Thus, under the Hudson standard, even truthful advertising can be proscribed if the government documents substantial interest that will be promoted or advanced by an advertising ban. In Posadas de Puerto Rico Assocs v. Tourism Co. (1980), for example, the Court ruled that restrictions on commercial speech that concerns a lawful activity (i.e. casino gambling) can still pass the four-pronged Hudson test if those restrictions are motivated by the state's concern for its residents' health, welfare, and safety. Although overturned in 1996, the aforementioned case still provides important insights to the discussion of the circumstances under which the state can proscribe commercial speech. 
In addition to the Central Hudson test, there are a number of federal and state laws that regulate advertising. The Federal Trade Commission (FTC) and its rulings constitute the majority of regulatory body. The FTC works under the Federal Trade Commission Act of 1914. In addition to defining the scope of federal regulation, the FTC determines the standards for industry and state regulatory institutes (Sheehan, 2004). The FTC's mission is to protect consumers from deceptive market practices and stimulate vigorous competition. Its statutory authority derives from the Federal Commission Act, which forbids unfair methods of competition. The FTC can prohibit both deceptive and unfair competition. In 1994, the Congress defined unfairness as a practice that is likely to cause considerable damage to consumers. Middleton and his colleagues say that unfairness, which is more likely to occur in a firm's treatment of its customers than in advertising, usually involves monetary harm caused by sellers "forcing" consumers into acquiring unwanted products and services (1997). More concerned with deception than unfairness, the FTC defines the former in terms of advertisements that contain material representations or omissions that are likely to mislead a reasonable consumer to his or her detriment (Sheehan, 2004; Middleton, et al., 1997). Material representations are statements that influence purchase-related decisions.

The Children's Television Act of 1990 is yet another regulatory mechanism that oversees televised commercial speech. Designed to serve children's educational and information needs, the Act limits commercial time on children's television programming to 10.5 minutes per hour on week-days and 12 minutes per hour on weekend.

As already stated, we believe that the existing regulations don't reflect the unique status of children. They don't fully account for children's susceptibility toward advertisers that often take unfair advantage of limited understanding of the nature and purpose of persuasive commercial appeals. Moreover, we think the regulations don't adequately reflect the ubiquitous nature of media particularly their manipulative messages. We don't believe that commercial speech is inherently problematic and needs stricter regulations. Instead, we believe that commercial speech is problematic when it's directed at children and is embedded with manipulative appeals. It is this combination of audience characteristics (i.e. children v. adults) with the nature of advertising (i.e. persuasive/manipulative v. informative) that creates a dangerous synergy necessitating a stricter oversight of commercial speech. In the following paragraphs, we try to justify the above position by revealing evidence that we think hasn't been properly addressed in previous discussions of children-oriented commercial speech.

\section{Children in the Marketplace of Ideas: Challenging the Rationale of Freedom of Expression in the Context of Persuasive Commercial Speech}

The rationale behind constitutional protection of commercial speech and the Hudson test in particular seems to be based, in large part, on the notion of the marketplace of ideas, a doctrine derived from John Milton's self-righting principle stating that truthful ideas will always prevail over lies and falsehood in a "fair" and unrestrained debate (Altschull, 1990). According to this logic, the public will find the truth when exposed to all the ideas of the "marketplace." In media industry, just like in any other domain of economy, a free and competitive market will create the best environment for adequately meeting the public's information needs. If ideas are "traded" or "exchanged" freely among "consumers," the "right" or "true" ideas will always win. Adam Smith's famous concept of "invisible hand" further developed the notion of the marketplace of ideas by elaborating on its mechanisms (Smith, 1904). Smith argued that producers or sellers of commodities, fearful of competition and anxious for financial prosperity, will stimulate the economy and offer the consumers the best possible combination of price and quality. Smith, just like Milton and other representatives of classic libertarian theory, thought that the marketplace of ideas was self-regulating and self-sustainable. Therefore, no state intervention was needed to control public communication.

The above marketplace of ideas model is based on a number of assumptions that, we believe, haven't been adequately reviewed. First, the model expects media markets to be competitive, have a large number of independent producers/sellers with a free flow of information and no substantial market entry barriers (Smith, 1904). The model further equates the nature (and workings) of the marketplace of ideas with that of a regular, economic marketplace of commodities. Most importantly, the model puts substantial "trust" in the public and its individual media consumers. It assumes that information consumption is rational.

We believe that a number of circumstances may undermine the aforementioned assumptions. First, for the "invisible hand" to work, there should be a strong, intermedia competition. It is the consumers' ability to choose among different (information) providers or "sellers" that keeps individual media outlets responsive to their audiences' interests. With an increasing concentration of media ownership, the public becomes more and more deprived of choice (Bagdikian, 2004). With no (or few) competitors, media outlets have no incentive to adequately serve their audiences. Today's increasing monopolization of media markets questions the efficiency of the invisible hand principle and, ultimately, the validity of the marketplace of ideas theory. 
The fundamental difference between media products and other commodities is yet another consideration that undermines the analogy between economic marketplace and the marketplace of ideas. The difficulty of applying the marketplace logic to mass media derives from the nature of information. Advertising content is a lot less tangible than consumer products or services. The meaning of commercial messages can be very abstract. Their "flaws" may not be as visible and detectable as the ones of other commodities. All in all, the marketplace of ideas is more complicated than the marketplace of any other products or commodities.

We now address the third and, possibly, most fundamental assumption that underlies the philosophy behind the First Amendment in the context of advertising-a belief in reason-based behavior. Philosophers, such as Locke and Milton, believed that every man was reasonable (Altschull, 1990). We know, however, that a large part of human behavior is motivated by emotions rather than reason. David Hume, for example, argued that all ideas derived from "impressions" or drives. He believed that emotions were an integral part of human nature. Although many reject the emotion-reason dichotomy (saying one doesn't exclude the other), studies have shown that certain emotional states tend to diminish people's cognitive abilities (Nabi, 2002). This is especially true for children who do not develop a comprehensive understanding of mental events, such as desires, beliefs, and motives until at least the age of seven (Wellman, 1990). The above beliefs in children's special status in the marketplace are well supported by a vast body of scholarship and empirical evidence. In particular, today we know that children below ages of six and seven are in the process of forming their cognitive potential. They don't have the necessary skills and experience to distinguish advertising from TV programming (Carroll, 1984). As a result, they don't apply the degree of skepticism when interpreting persuasive messages (Kunkel, 2001; John, 1999; Young, 1990) that adult consumers do.

\section{Courts, Children and Media}

Courts have consistently recognized the need to protect children from the influences of the marketplace. They have proclaimed that children require special treatment and protection from marketers' targeting efforts. As Justice Rutledge stated, the sustainability of a democratic society depends "upon the healthy, well-rounded growth of young people into full maturity as citizens" (Prince v. Massachusetts, 1944). For example, in Capital Broadcasting Co. v. Mitchell, a pre-Virginia Pharmacy Board case, the (broadcasting) proscription of cigarette advertisements survived the First Amendment challenge when the district court took into account the broadcast media's unique accessibility to children (1971). The court concluded that because of its unique accessible nature, broadcast media should enjoy a lower level of constitutional protection. The court further argued that the First Amendment rights of adults can be outranked by the vital interest in protecting children. The court's decision was supported by the federal district court in Washington, D.C. and affirmed by the Supreme Court in 1972. In an earlier case, the Supreme Court's concern for the well-being of children resulted in upholding a state law that banned the distribution of pornographic materials to minors (Ginsberg v. New York, 1968). In Ginsberg v. New York, the Court proclaimed that certain cultural products can cause harm to children, and that children must be entitled to protection from such materials. Later, in 1982, the Court unanimously discarded a First Amendment challenge allowing a state ban on the circulation of materials that portrayed children involved in sexual conduct (New York v. Ferber, 1982). In New York v. Ferber, the court agreed that because the state had a "compelling interest" in protecting children and because the value of such speech was "de minimus," (i.e. of minimum importance), the protection of children had to override the First Amendment right of access to pornography. The Federal Communications Commission v. Pacifica Foundation (1978) was yet another post-Virginia Pharmacy Board case that recognized the unique legal status of children. The case is interesting also because it illustrates the Court's view of television as a medium that has an overtly ubiquitous and uniquely pervasive presence in people's lives. Moreover, the Court agreed with the idea that broadcasting is highly accessible to children. The review of the aforementioned cases indicates that the Virginia Pharmacy case did not impose insurmountable, constitutional barriers to restricting certain forms of (commercial) speech directed at children, especially when the speech is communicated through broadcast media.

\section{Why TV Commercials}

We focus on TV commercials because of the unique role television as a medium plays in children's lives. As Albert Bandura's social learning theory posits, television is one of the major predictors of children's worldviews and behaviors. It serves as a vehicle of socialization and a source of acceptable norms and expectations, such as gender roles. The theory states that children accept what is "real" from television (Bandura, 2002). Moreover, studies have indicated that children perceive the televised presentation of reality as more "lively," "satisfying," and "fun" than the real life (Schramm, Lyle, \& Parker, 1961). Besides, television viewing has been blamed in producing social and cognitive ills, such as attention deficit and poor concentration, inactivity and obesity, as well as aggression. As already stated, courts have recognized the unique role of television in children's lives, by 
emphasizing broadcast media's particular accessibility to children and by granting television a lower level of constitutional protection (Prince v. Massachusetts, 1944; Capital Broadcasting Co. v. Mitchell, 1971). As Justice Stevens stated in Federal Communications Commission v. Pacifica Foundation, a post-Virginia Pharmacy Board case, "of all forms of communication, broadcasting has the most limited First Amendment protection." "Broadcasts extend into the privacy of the home and it is impossible completely to avoid," he continued (1978). The aforementioned case is noteworthy because it reconfirms the idea that each medium of mass communication presents a special First Amendment issue.

\section{Why Child-oriented Persuasive TV Commercials are Deceptive}

In the following section, we provide a context for evaluating the issue of children's advertising by reviewing what is known about the nature of persuasive messages and the FTC's standard for deceptive commercial speech. This section also readdresses the developmental differences (i.e. between adults and children) that influence children's ability to recognize advertisers' commercial intent.

In 1974, Nicosia defined the term advertising as a notice to inform or to make known. Almost a decade later, when the use of manipulative techniques in marketing became vastly popular, media scholars changed the initial definition of advertising by describing it as a paid message that aims to persuade (Dunn \& Barban, 1986). In this study, we will operationally define persuasive advertising in terms of commercials that employ peripheral cues (Cacioppo, Petty, Chuan, \& Rodriguez, 1986; Petty \& Cacioppo, 1986). As Sheehan (2004) points out, peripheral cues or appeals are pieces of information that are irrelevant to or remotely associated with the object of the message (e.g. images, sounds, jargon, endorsements, animation, etc). A commercial featuring a song that the target audience likes or a person whom the audience views as appealing are examples of peripheral advertising. As opposed to central cues, which provide clear brand/product data (e.g. product characteristics, such as durability, compatibility, etc.), peripheral cues, also known as manipulative appeals, emphasize things that are irrelevant to the actual merits of the advertised product.

While central cues produce attitude change through an evaluation of the arguments within the message, peripheral advertising influences attitudes through mostly emotional appeals. It causes consumers not to evaluate advertising messages in a rational way. It provides minimum information about a product's or service's attributes. In other words, peripheral ads aim to cultivate positive attitudes without those individuals ever thinking about the merits of the advertised product/service (Petty \& Wegener, 1998; Petty \& Wegener, 1999). Often, they suggest how we as consumers will feel if we purchase the product or service. One of Marlboro's ads, for example, states that smoking Marlboros will make consumers feel manlier. Drinking Bud Light will help "make friends." Soft drink marketing, which targets primarily youth, is a category of promotion that relies heavily on peripheral cues (Arthur, 1995). Instead of focusing on quality of ingredients and flavor, soft drinks commercials provide consumers with entraining and romantic images that produce favorable brand attitudes (e.g. Coca Cola featuring the antics of a family of polar bears drinking Coke without hardly any information about the product itself).

As already stated, we believe that persuasive TV commercials when directed at children are deceptive. According to the FTC standard, for an ad to be deceptive it must contain material representations or omissions that are likely to mislead a reasonable consumer. Being abstract and utterly nonfactual, persuasive ads embedded with peripheral cues are likely to mislead children by concealing their commercial intent (i.e. as they tend to focus on things unrelated or marginally related to the advertised product or service). Those ads leave an impression of "friendly" offers rather than commercial solicitations (Sheehan, 2004). Often communicated in "sneaky" and "subliminal" ways, peripheral ads implicitly suggest, rather than state a meaning. As such, they are likely to be deceptive for children. We agree that deceptiveness is a relative category. According to the FTC, deceptiveness is determined by the overall impression an ad leaves (Middleton, et al., 1997). In fact, the meaning or interpretation of an ad can vary from one group of consumers to another. As Middleton points out, the same ad, while accurate and truthful for one group of consumers, can be qualified as deceptive for another (e.g. promises of easy weight loss directed at obese versus average consumers). By the same token, while persuasive ads with peripheral appeals might not necessarily mislead adult audiences (and be qualified as "misleading"), they are likely to mislead children, and make them take commercial claims at their face value (note: we know that, based FTC's norms, commercial messages are required to be clearly identifiable as such to their intended audiences-children in our case).

Furthermore, the very nature of persuasive advertising makes them emotionally embedded. This is yet another reason why those advertisements escape children's cognitive safeguards. Some argue that companies make products and then use peripheral advertisements to create emotional needs among consumers that the products they have made can gratify (Philips, 1997). Associating a brand or a product with happiness and fun is one of the 
most commonly used techniques in targeting children. We know, on the other hand, that positive emotions are related to decreased depth of processing (Nabi, 2002). People in a positive state of mood aren't particularly critical and systematic in analyzing information and making purchase-related decisions. They interpret communication messages through shallow heuristics (i.e. simplified mental images or shortcuts derived from past experiences), rather than systematic thinking. Experiencing positive emotions can therefore block children's information processing abilities while making them utterly "manipulatable" and further vulnerable to persuasive messages.

Persuasive advertisements to children are, thus, misleading and deceptive because they create unrealistic expectations regarding the quality and performance of products. According to the FTC's standard, advertisements must not contain statements or omissions that produce false impressions by implication. As Middleton and his colleagues state, an implication is a false meaning that people add to an ad as a result of the impression the ad creates. When exposed to persuasive commercials, which often employ special camera and editing techniques (e.g. close-ups, moving images of toys that can't move by themselves), children develop "over-expectations" and certain beliefs about the advertised product. When those expectations aren't met children feel frustrated, deceived, and unhappy (Robertson, 1979; Ward et al., 1977).

Additionally, we believe that persuasive ads meet the materiality part of the FTC's standard for deception because they produce substantial behavioral effects. As already stated, those ads leave an impression of "friendly" suggestions rather than commercial solicitations (Sheehan, 2004). We know that a suggestive message can have stronger attitudinal and behavioral outcome than an explicitly stated message (Philips, 1997; McDonald, 1992). The reason suggestions have stronger influence than explicit statements is that suggestions have the potential to override consumers' rational decision making. Moreover, they tend to employ power drives, such as love, status, happiness, and fear, which (as already shown) further undermine rational information processing. A number of studies on commercials for candy, snacks, and fast food have documented that persuasive ads are very effective in making children like and request the products advertised in TV commercials (Borzekowski \& Robinson, 2001).

\section{Weighing the Pros/cons and Helping Regulators to Accomplish Their Line-drawing Task}

Tightening the regulation of advertising that targets children posits, however, a number of challenges. Increasing restrictions on commercial speech might potentially lead to the disappearance of programming for young children since advertising funds support the vast majority of children-oriented TV programs (Sheehan, 2004). The FCC requires that networks broadcast at least three hours of educational programming every week in order to keep their licenses. Some think that it would be hardly possible to meet this requirement without advertising patronage. Some also argue that advertising is an important vehicle for consumer education. Advertisements teach children how to evaluate products, services and brands.

Given the existing base of knowledge about children's comprehension of advertising messages and the nature of persuasive appeals in televised commercials, we believe that a number of circumstances outweigh the aforementioned arguments in support of loosely regulated advertising industry. We know that because of their manipulative nature, persuasive TV ads can contribute to a number of behavioral, emotional, and developmental problems, such as parent-child conflicts (Robertson, 1979), health complications (Troiano \& Flegal, 1998), unhappiness (Martin \& Kennedy, 1993; Richins, 1991), and increased sense of materialism (Greenberg \& Brand, 1993; Moschis \& Moore, 1982).

Numerous countries have established tight restrictions on advertising to children and still have abundant programming for their youth. Belgium for example, issued the five-minute rule in 1995, an ordinance that prohibits children's programs being immediately followed or preceded by children's advertisements. In the same year, Norway proclaimed a total ban on television commercials directed at children, a decree, which was later adopted by Sweden.

We agree that there is no a simple solution to the "clash" of values that emerges when the state regulates commercial speech to protect children. What we argue is that free speech is only one of the several values we must safeguard. We believe that it should be balanced by children's right to healthy and protected childhood.

In light of the above evidence, proscribing child-oriented persuasive TV adverting seems fairly straightforward. As we've already established, persuasive commercials directed at children meet all three elements of the FTC's standard for deception-being material and misleading to an ordinary consumer. Therefore, those advertisements can be banned under section five of the FTC Act, which prohibits unfair and deceptive commercial activities (15 U.S.C. $\S 45$ 2000). In fact, the FTC has a long and highly successful history of protecting children from deceptive marketing practices. For example, in the last three decades, the Commission initiated a number of 
cases challenging deceptive performance statements in toy commercials (e.g. Lewis Galoob Toys, Inc., 114 F.T.C. 187 (1991); Hasbro, Inc., 116 F.T.C. 657 (1993)). In each of the aforementioned cases, the advertisement at issue was examined from the perspective of a child in the age group to which the toy was targeted. Although the advertisements were not recognized as misleading to an adult audience (since an adult viewer could understand the marketers' use of perpheral techniques to enhance the perceived performance quality of the toy), the ads were qualified as deceptive, because children were thought to wrongly expect the advertised toys to perform in the way that was demonstrated (advertised) on TV.

\section{Conclusions}

Our main goal in this inquiry was to reveal the unique vulnerability of children in the face of marketers' sophisticated targeting efforts. We would like the industry and the regulators to realize that using persuasive techniques toward children might be reprehensible, not only morally or ethically, but also legally. In promoting a cereal, a toy, or any other consumer product, advertisers should abstain from associating those products with love, happiness, romance, and other emotions that, while in most cases irrelevant to advertised products (i.e. peripheral), make children a promise advertisers can't keep.

As indicated above, there are ways to regulate persuasive commercial speech and draw the line between peripheral and informative advertising. Whether or not the regulators would want to draw that line is not certain. What is certain, however, is that today, when the proliferation of communication technologies has blurred the boundaries between commercial and noncommercial content, children's right to safe and healthy childhood is more at risk than ever before. With the expansion of children's access to the Internet and the ever-increasing sophistication of advertising campaigns, children are bombarded with myriads of commercial solicitations. Many of them are embedded with dynamic, technically-advanced, and ever latent persuasive messages aiming to manipulate children, emotionally, attitudinally, cognitively, and behaviorally. We believe that uncovering the true meaning of those messages for our children while safeguarding them against the manipulative strategies of the marketplace is our paramount responsibility.

\section{References}

Adler, R., Lesser, G. S., Meringoff, L. K., Robertson, T. S., Rossiter, J. R., \& Ward, S. (1980). The effects of television advertising on children. Lexington, MA: Lexington Books.

Altschull, H. J. (1990). From Milton to McLuhan: The ideas behind American journalism. New York: Longman.

American Academy of Child and Adolescent Psychology. (2001). Obesity in children and teens. Retrieved January 21, 2012, from http:/www.aacap.org/publications/factsfam/79.htm

Arthur, I. (1995). Make love not war. Bombay, India: Hindustan Thompson.

Atkin, C. K. (1980). Effects of television advertising on children. In E.L. Palmer \& A. Dorr (Eds.), Children and the faces of television: Teaching, violence, selling (pp. 287-305), New York: Academic Press.

Atkin, C. (1995). Survey and experimental research on effects of alcohol advertising. In S. Martin (Ed.), The effects of the mass media on the use and abuse of alcohol (pp. 39-68).

Bagdikian, B. (2004). The new media monopoly. Boston: Beacon Press.

Bandura, A. (2002). Social cognitive theory of mass communication. In J. Bryant and D. Zillmann, Media effects: Advances in theory and research (pp. 121-153). Mahwah, NJ: Lawrence Erlbaum.

Bakir, A., \& Vitell, J. S. (2010). The ethics of food advertising targeted toward children: Parental viewpoint. Journal of Business Ethics, 91(2), 299-311. http://dx.doi.org/10.1007/s10551-009-0084-2

Blosser, B., \& Roberts, D. (1985). Age differences in children's perceptions of message intent: Responses to TV news, commercials, educational spots, and public service announcements. Communication Research, 12, 455-484.

Boorstin, D. (1961). The image: A guide to pseudo-events in America. New York: Vintage.

Borzekowski, D. L. G., \& Robinson, T. N. (2001). The 30-second effect: An experiment revealing the impact of television commercials on food preferences of preschoolers. Journal of the American Dietetics Association, 101, 42-46.

Bruner, J. S. (1966). On cognitive growth I \& II. In J. S. Bruner, R. R. Oliver, \& P. M. Greenfield (Eds.), Studies in cognitive growth (pp. 1-67). New York: Wiley.

Buijzen, M., \& Valkenburg, P.M. (2000). The impact of television advertising on children's Christmas wishes. 
Journal of Broadcasting \& Electronic Media, 44, 456-470.

Cabletelevision Advertising Bureau. (2006). 2005 cable tv facts, the big erosion picture: Ad-supported cable vs. all broadcast. Retrieved March 24, 2012, from http://www.onetvworld.org/?module=displaystory\&story_id $=1257 \&$ format $=\mathrm{html}$

Cacioppo, T. J., Petty, E. R., Chuan K. F., \& Rodriguez, R. (1986). Central and peripheral routes to persuasion: An individual difference perspective. Journal of Personality and Social Psychology, 51(5), 1032-1043.

Capital Broadcasting Co. v. Mitchell, 333 F. Supp. 582 (D.D.C. 1971), aff'd, 405 U.S. 1000 (1972).

Carroll, J. (1984). The role of cognitive development in children's understandings of their own feelings. Child Development, 55, 1486-1492.

Center for Media Education. (1997). Children and television. Retrieved January 17, 2012, from

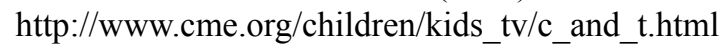

Central Hudson Gas \& Electric Corp. v. Public Service Commission of New York, 447 U.S. 557 (1980).

Children's Advertising Review Unit. (2006). Self-regulatory program for children's advertising. New York: Children's Advertising Review Unit.

Collins, R. L. (2008). Media multitasking: issues posed in measuring the effects of television sexual content exposure. Communication Method and Measures, 2(1-2), 65-79.

Craswell, R. (1985). Interpreting deceptive advertising. Boston University Law Review, 65(4), 657-732.

Dunn, S. W., \& Barban, A. (1986). Advertising, its role in modern marketing. Chicago: Dryden.

Edenfield v. Fane, 507 U.S. 761 (1993).

Etzioni, A. (2004). Do children have the same First Amendment rights as adults? On protecting children from speech. Chicago-Kent Law Review, 79(3).

Federal Communications Commission v. Pacifica Foundation, 438 U.S. 726 (1978).

Friestad, M., \& Wright, P. (1994). The persuasion knowledge model: How people cope with persuasion attempts. Journal of Consumer Research, 21, 1-31.

Gantz, W., Schwartz, N., Angelini, J., \& Rideout, V. (2007). Food for thought: Television food advertising to children in the United States. Menlo Park, CA: Henry J. Kaiser Family Foundation.

Garfield, A. E. (2005). Protecting children from speech. Florida Law Review, 57(565), 13-32.

Gibbs, N., August, M., Cole, W., Lofaro, L., Padgett, T., Ressner, J., \& Winters, R. (2001). Who's in charge here? Time, 158, 40-48.

Ginsberg v. New York, 390 U.S. 629, 637-643 (1968).

Goldberg, M., Gorn, G., \& Gibson, W. (1978). TV messages for snacks and breakfast foods: Do they influence children's preferences? Journal of Consumer Research, 5, 73-81.

Greenberg, B., \& Brand, J. (1993). Television news and advertising in the schools: The "Channel One" controversy. Journal of Communication, 43(1), 143-151.

Grube, J. W. (1995). Television alcohol portrayals, alcohol advertising, and alcohol expectancies among children and adolescents. In S. E. Martin (Ed.), The effects of the mass media on use and abuse of alcohol (pp. 105-121). Bethesda, MD: National Institute on Alcohol Abuse and Alcoholism.

Hasbro, Inc., 116 F.T.C. 657 (1993)

Hoffner, C., \& Cantor, J. (1985). Developmental differences in responses to a television character's appearance and behavior. Developmental Psychology, 21, 1065-1074.

Hoffner, C., Cantor, J., \& Thorson, E. (1989). Children's responses to conflicting auditory and visual features of a televised narrative. Human Communication Research, 16, 256-278.

Holsti, O.R. (1969). Content analysis for the social sciences and the humanities. Reading, MA: Addison-Wesley.

John, D. R. (1999). Consumer socialization of children: A retrospective look at twenty-five years of research. Journal of Consumer Research, 26 (December), 183-213.

Jowett, B. (1892). The dialogues of Plato. London: Macmillan and Co.

Kolish, E. D., \& Enright, M. (2010). Food advertising for children. Health Affairs, 29(8), 1556. 
http://dx.doi.org/10.1377/hlthaff.2010.0615

Krippendorf, K. (1980). Content analysis: An introduction to its methodology. Beverly Hills, CA: Sage Publications.

Kunkel, D. (2001). Children and television advertising. In D. G. Singer \& J. L. Singer (Eds.), The handbook of children and media (pp. 375-394). Thousand Oaks, CA: Sage Publications.

Levine, M. (2007). How materialism hurts our kids: Privilege. Ethnic News Watch, 22(1), 33.

Lewis Galoob Toys, Inc., 114 F.T.C. 187 (1991)

Lin, Y. (1997). Put a rein on that unruly horse: Balancing the freedom of commercial speech and the protection of children in restricting cigarette billboard advertising. Washington University Journal of Urban and Contemporary Law, 52(307).

Martin, M. C., \& Kennedy, P.F. (1993). Advertising and social consequences for female preadolescents and adolescents. Psychology \& Marketing, 10, 513-530.

McDonald, C. (1992). How advertising works: A review of current thinking. Detroit, MI: NTC Publications.

McNeal, J. (1998). Tapping the three kids' markets. American Demographics, 20(4), 37-41.

Middleton, K. R., Lee, W. E., \& Chamberlin, B. F. (2004). The law of public communication. Boston: Allyn \& Bacon.

Moore, E. S. (2006). Its child's play: Advergaming and the online marketing of food to children. Menlo Park, CA: Henry J. Kaiser Family Foundation.

Morgan, M., Fairchild, R., Phillips, A., Stewart, K., \& Hunter, L. (2009). A content analysis of children's television advertising: focus on food and oral health. Public Health Nutrition, 12(6), 748-755. http://dx.doi.org/10.1017/S1368980008003169

Moschis, G. P., \& Moore, R. L. (1982). A longitudinal study of television advertising effects. Journal of Consumer Research, 9, 279-286.

Nabi, R. L. (2002). Discrete emotions and persuasion. In J. P. Dillard \& M. Pfau (Eds.), The persuasion handbook: Developments in theory and practice (pp. 289-308). Thousand Oaks, CA: Sage Publications, Inc.

New York Times v. Sullivan, 376 U.S. 254 (1964).

New York v. Ferber, 458 U.S. 747 (1982).

Ohralik v. Ohio State Bar Association, 436 U.S. 447 (1978).

Petty, R. E., \& Cacioppo, J. T. (1986). Communication and Persuasion: Central and Peripheral Routes to Attitude Change. New York: Springer-Verlag.

Petty, R. E., \& Wegener, D. T. (1998). Attitude change: Multiple roles for persuasion variables. In D. T. Gilbert, S. Fiske, \& G. Lindzey (Eds.), Handbook of social psychology (pp. 323-390). Boston, MS: McGraw-Hill.

Petty, R. E., \& Wegener, D. T. (1999). The Elaboration Likelihood Model: Current Status and Controversies. In S. Chaiken \& Y. Trope (Eds.), Dual process theories in social psychology (pp. 41-72). New York: Guilford Press.

Philips, M. J. (1997). Ethics and manipulation in advertising. Answering a flawed indictment. Westport, CTL Quorum.

Posadas de Puerto Rico Assocs v. Tourism Co., 478 U.S. 328 (1986).

Postman, N. (1985). Amusing ourselves to death: Public discourse in the age of show business. New York: Viking.

Prince v. Commonwealth of Massachusetts, 321 U.S. 158 (1944).

Richins, M. (1991). Social comparison and the idealized images of advertising. Journal of Consumer Research, $18,71-83$.

Riffe, D., Lacy, C., \& Fico, F. (1998). Analyzing media messages. Using quantitative content analysis in research. Mahwah, NJ: Lawrence Erlbaum Associates, Inc.

Roberts, D. (1982). Children and commercials: Issues, evidence, interventions. Prevention in Human Services, 2 , 19-35. 
Roberts, D., Foehr, U., Rideout, V., \& Brodie, M. (1999). Kids \& media in the new millennium: A comprehensive national analysis of children's media use. Menlo Park, CA: Kaiser Family Foundation.

Robertson, T. (1979). Parental mediation of advertising effects. Journal of Communication, 29(1), 12-25.

Robertson, T., \& Rossiter, J. (1974). Children and commercial persuasion: An attribution theory analysis. Journal of Consumer Research, 1, 13-20.

Robertson, T., Ward, S., Gatignon, H., \& Klees, D. (1989). Advertising and children: A cross- cultural study. Communication Research, 16, 459-485.

Ross, C. J. (2000). Anything goes: Examining the state's interest in protecting children from controversial speech. Vanderbilt Law Review, 53(427).

Rossiter, J., \& Robertson, T. (1974). Children's television commercials: Testing the defenses. Journal of Communication, 24(4), 137-144.

Schramm, W., Lyle, J., \& Parker, E. B. (1961) Television in the Lives of Our Children. Stanford: Stanford Univ. Press.

Schudson, M. (1984). Advertising, the uneasy persuasion. New York. Basic Books.

Sheehan, K. (2004). Controversies in contemporary advertising. Thousand Oaks, CA: Sage Publications, Inc.

Sheikh, A., \& Moleski, M. (1977). Conflict in the family over commercials. Journal of Communication, 27(1), 152-157.

Slater, M. D., Rouner, D., Domenech-Rodriguez, M., Beauvais, F., Murphy, K, \& Van Leuven, J. K. (1997). Adolescent responses to TV beer ads and sports content/context: Gender and ethnic differences. Journalism and Mass Communication Quarterly, 74, 108-122.

Smith, A. (1904). An inquiry into the nature and causes of the wealth of nations. London: Methuen and Co., Ltd.

Strasburger, V. C. (2001). Children, adolescents, drugs, and the media. In D. G. Singer \& J. L. Singer (Eds.), Handbook of children and the media (pp. 415-445). Thousand Oaks, CA: Sage.

Troiano, R. P., \& Flegal, K. M. (1998). Overweight children and adolescents: Description, epidemiology and demographics. Pediatrics, 101, 497-504.

Turow, J. (1981). Entertainment, education, and the hard sell: Three decades of Network children's television. New York: Praeger.

Valentine v. Chrestensen, 316 U.S. 52. (1942).

Virginia State Board of Pharmacy v. Virginia Citizens Consumer Council, Inc., 425 U.S. 748 (1976).

Ward, S., Wackman, D., \& Wartella, E. (1977). How children learn to buy: The development of consumer information processing skills. Beverly Hills, CA: Sage Publications.

Wellman, H. M. (1990). The child's theory of mind. Cambridge, MA: MIT Press.

Wood, K. (2000). Freedom of Expression: Terms, dates, and concepts. Retrieved October 11, 2007, from: http://kylewood.com/firstamendment/terms.htm

Wulfemeyer, K. T., \& Mueller, B. (1992). Channel One and commercials in classrooms: Advertising content aimed at students. Journalism Quarterly, 69, 724-742.

Young, B. (1990). Television advertising and children. Oxford, Clarendon Press. 